\title{
A gramática no ensino de língua portuguesa: à busca de compreensão ${ }^{1}$
}

\section{Grammar in Portuguese teaching: the search for understanding}

Graziela Angelo*

Universidade Federal de Santa Maria - UFMS

Santa Maria - Rio Grande do Sul / Brasil

\begin{abstract}
RESUMO: O presente artigo discute a ideia amplamente divulgada na esfera acadêmica de que o ensino da gramática de Língua Portuguesa, de décadas atrás, no Brasil, se constituiu como um panorama contínuo e homogêneo. Na busca de compreender esse passado, foram analisadas entrevistas com algumas professoras de Língua Portuguesa que trabalharam nas décadas de 1950 a 1970 no ensino público paulista, a fim de investigar como se constituíram seus discursos a respeito do ensino de gramática no processo de rememoração. Foi possível verificar que a permanência de uma tradição e a instauração de novas posturas coexistiram num mesmo período de tempo, havendo espaço para posturas distintas no ensino da gramática.
\end{abstract}

PALAVRAS-CHAVE: língua portuguesa, ensino, gramática

ABSTRACT: This paper discusses the widely spread idea that Portuguese grammar teaching from decades ago, in Brazil, was a continuous and homogenous panorama. In order to understand this past, this paper reports an analysis of interviews with some Portuguese language teachers who worked in São Paulo public schools in the 1950 s to 1970 s with the aim of investigating how their discourses on grammar teaching were formed in the process of rememoration. This study observed that the permanence of a tradition and the rise of a new attitude coexisted in the same period of time, opening space for distinct attitudes in grammar teaching. KEYWORDS: Portuguese language, teaching, grammar

${ }^{1} \mathrm{O}$ presente artigo é resultado do meu trabalho de doutorado, defendido no Programa de Pós-Graduação em Linguística Aplicada da Unicamp, em 2005, sob a orientação da Professora Doutora Raquel Salek Fiad.

* glangelo@terra.com.br 


\section{Introdução}

Há várias aproximações ao passado do ensino de uma disciplina curricular, seja, por exemplo, por meio da documentação oficial escolar, cadernos de alunos, diários de classe, publicação pedagógica, livros didáticos, dentre outras tantas fontes (CHERVEL, 1990) que permitem iluminar, embora de forma sempre oblíqua, parcial, irremediavelmente embaçada, a visão de um tempo distante do momento presente.

Neste artigo, volto-me ao passado do ensino de uma disciplina em particular, a Língua Portuguesa, e para me aproximar da sua história, tomo como via de acesso não textos escritos, documentados, mas a palavra (oral) do professor dessa disciplina, quase sempre ausente dos textos da esfera acadêmica, como um canal para adentrar a rede de significados que perpassam um tempo escolar vivido há várias décadas.

Nesse percurso, focalizo o chamado ensino tradicional de Língua Portuguesa, para investigar o seu mais representativo componente, qual seja, o ensino da gramática, cuja primazia sobre o trabalho com o texto, talvez seja explicada, segundo Soares (2002), pela força da tradição, que vem desde os tempos do sistema jesuítico, ou pelo espaço vazio que o abandono da retórica e poética deixou nesse ensino.

Falar da história desse ensino tradicional, nos dias de hoje, ainda parece exigir, daquele que o investiga, um certo distanciamento, um despojamento das reiteradas formas de identificá-lo negativamente, que foram insistentemente apontadas ao longo das últimas décadas, principalmente através da produção acadêmica de muitos linguistas brasileiros, e que passaram a constituir e legitimar uma certa memória desse ensino, traduzida em termos de falta, fragilidade, reprodução de esquemas, continuidade e homogeneidade.

Por entender que o conhecimento da história do ensino tradicional de Língua Portuguesa, e em particular o do ensino da gramática, não se constitua de forma linear, transparente, nem definitiva, ${ }^{2}$ mas se compõe de variadas vozes que dialogam e ressoam entre si permanentemente, estabelecendo as mais variadas relaçōes, e por considerar que a voz da academia é mais uma dentre elas -, embora reconhecidamente a de poder, pelo caráter científico que a

\footnotetext{
${ }^{2}$ Como parecem fazer crer muitos textos acadêmicos e também documentos oficiais para o ensino de língua materna, principalmente os publicados das décadas de 1970 e 1980, conforme Angelo (2005).
} 
determina -, é que me lanço nessa investigação à busca de possíveis “outros sentidos" a constituir essa história em que certamente há lugar também para a palavra do professor.

Este trabalho tem por finalidade divulgar resultados que obtive a partir da análise de um corpus de pesquisa com entrevistas orais realizadas com professoras de Língua Portuguesa, já aposentadas, e que trabalharam numa etapa reconhecidamente denominada de ensino tradicional. Dos vários tópicos abordados, privilegio, neste artigo, o ensino da gramática, por sua representatividade e pela ampla discussão que ainda hoje suscita quando se fala de ensino de língua.

Foi objetivo da pesquisa investigar como se constituíram os discursos das entrevistadas a respeito do ensino de gramática, ou melhor dizendo, que vozes sociais estavam presentes no processo de rememoração desses sujeitos e que relações, que dinâmica elas estabeleceram entre si na situação de entrevista.

Defendo neste artigo a necessidade de se abrir espaço para a reflexão sobre o passado do ensino da gramática, que, no meu entender, não se resume a uma voz monológica, que circula na esfera acadêmica. A palavra das professoras, nesse sentido, é mais uma escuta a movimentar sentidos, é um exercício de compreender o seu passado.

\section{Referenciais teórico-metodológicos}

A perspectiva teórica adotada é a sócio-histórica, de linha bakhtiniana, que toma a interação verbal como o lugar da produção da linguagem e da constituição dos sujeitos.

Nessa direção, retomando Faraco (2003) e Brandão (2004), a interação socioverbal engloba qualquer tipo de comunicação verbal ${ }^{3}$ e cada evento interacional é compreendido dentro de um quadro complexo de relações socioculturais, que envolve tanto a situação mais imediata quanto o meio social mais amplo, ambos condicionadores do que se diz e de sua significação.

$\mathrm{Na}$ esteira desses estudos,

a linguagem verbal não é vista primordialmente como sistema formal, mas como atividade, como um conjunto de práticas socioculturais [...] que estão atravessadas por diferentes posiçôes avaliativas sociais (concretizam diferentes vozes sociais). (FARACO, 2003, p. 105-6).

${ }^{3} \mathrm{O}$ diálogo face a face é apenas um deles. 
Como o dizer está embasado numa prática social e histórica, ele está inevitavelmente saturado de valores que decorrem dessa mesma prática. Esses diferentes dizeres ou "verdades sociais" se materializam semioticamente e se constituem em línguas sociais ou vozes ${ }^{4}$ que caracterizam a realidade da linguagem como altamente estratificada (heteroglótica) e atravessada por embates constantes (heteroglossia dialogizada). É justamente no conjunto dessas várias vozes em contínuos embates (BAKHTIN, 1934-1935/1998) que emergem os enunciados, que se manifestam como uma tomada de posição axiológica em resposta ao já-dito e, ao serem ditos, esperam uma resposta, nunca neutra, mas sempre avaliativa.

Nessa abordagem, são as relações dialógicas, em sentido amplo, e não os eventos em si, que interessam, concebidas como relações de sentido que decorrem da responsividade, ou seja, da tomada de posição axiológica que faz parte de todo enunciado (BAKHTIN, 1959-61/2000).

Os sujeitos que participam dessas relações, ao produzirem linguagem, vão se constituindo, ao mesmo tempo que constituem a própria linguagem, entendida como o lugar onde o ideológico se manifesta na palavra, de forma objetiva e material. Tais sujeitos são entendidos como indivíduos socialmente organizados, definidos como feixes de relações sociais - feixes múltiplos e móveis - e são marcados por tensa heterogeneidade (FARACO, 2003).

Com esse apoio teórico, o trabalho mobilizou as noções de vozes sociais e relaçôes dialógicas para a discussão e análise dos dados.

Para a elaboração da pesquisa foi construído um corpus, formado de entrevistas, em que cada texto foi entendido como um conjunto de signos verbais produzidos por sujeitos sociais historicamente situados, com uma determinada visão de mundo, com um universo de valores com que interage. A análise desses textos implicou necessariamente as suas condições de produção, tanto os aspectos mais gerais (o meio social mais amplo) como os mais específicos (a situação mais imediata) (BAKHTIN, 1929/1986).

A leitura realizada visou a uma compreensão dos textos produzidos - $\mathrm{e}$ não a uma explicação -, direção essa que aponta para o possível (BAKHTIN, 1974/2000), dada a dimensão da pluralidade que sempre envolve a produção e recepção verbais (sempre contextualizadas).

${ }^{4}$ Complexos semiótico-axiológicos com os quais um determinado grupo humano diz o mundo. 
O corpus construído foi formado por quatro entrevistas orais semiestruturadas, feitas por mim, com quatro professoras de Língua Portuguesa, ${ }^{5}$ de 76 a 78 anos, aposentadas há vários anos. Além da idade e situação profissional em comum, compartilhavam o fato de terem trabalhado no ensino público estadual paulista, no período de início dos anos 1950 até aproximadamente fins dos anos 1970, tendo exercido a docência por vários anos na cidade de Campinas (SP); tinham em comum também o fato de terem lecionado a maior parte da vida profissional no antigo curso ginasial, na escola pública não democratizada, e terem sua formação em Letras antes da introdução dos estudos linguísticos no curso superior. ${ }^{6}$

Nas entrevistas, busquei trazer à tona a história de vida profissional das entrevistadas a partir de vários tópicos sobre o ensino de língua, dentre eles o ensino de gramática. As entrevistas foram gravadas e transcritas por mim; posteriormente foram conferidas pelas entrevistadas e, finalmente, foram-me cedidas por meio de carta de cessão de direitos. ${ }^{7}$

O que foi produzido nas entrevistas é a imagem que as docentes construíram do passado no momento da entrevista (BOSI, 1994), ou seja, uma seleção de acontecimentos, um externar de informações e opiniōes que passa pelo crivo avaliativo do presente. Segundo Halbwachs (apud BOSI, 1994, p. 54), os fatos narrados, mediados pela memória, não podem ser interpretados como uma transposição tal como ocorreram, mas como um trabalho; por isso, não podem ser interpretados como "a" verdade, mas somente como "mais uma” versão:

[q]ual versão de um fato é a verdadeira? Nós estávamos e sempre estaremos ausentes dele. Não temos, pois, o direito de refutar um fato contado pelo memorialista, como se ele estivesse no banco dos réus para dizer a verdade, somente a verdade. Ele, como todos nós, conta a sua verdade. (BOSI, 2003, p. 65).

\footnotetext{
${ }^{5}$ No desenvolvimento do trabalho, a identificação das entrevistadas é feita por meio das letras A, B, C e D.

${ }^{6}$ Segundo Kato (1983), a implantação da Linguística no Currículo Mínimo de Letras se deu a partir de 1963 .

${ }^{7}$ A opção por trabalhar dessa forma é de caráter metodológico, inspirada na metodologia da História Oral, que garante ao entrevistado o direito de tomar conhecimento do que falou, conferir a transcrição e, caso pretenda, alterar o texto transcrito. As leituras de Meihy (1996), Garnica (2004), Guedes-Pinto (2000) e Bosi (2003) foram de importância para a construção do corpus de pesquisa.
} 
Colocando-me diante dessa perspectiva, passo a relatar as reflexões que a leitura dos textos suscitou, acenando para a emergência de regularidades e de tomadas de posições avaliativas dos sujeitos.

\section{Análise}

Primeiramente, alguns esclarecimentos sobre as condições de produção das entrevistas.

No âmbito da situação mais imediata, é preciso dizer que as entrevistadas foram contatadas por mim e informadas de que o objetivo da entrevista era recolher dados a respeito da sua vida profissional, dados esses que iriam subsidiar a realização de meu trabalho de doutorado, voltado à reflexão do ensino tradicional de língua portuguesa. Foram informadas também das etapas de construção do corpus de pesquisa, ${ }^{8}$ que culminaria com uma carta de cessão de direito das entrevistas por parte das entrevistadas. Acredito que o esclarecimento prévio dessas etapas tenha permitido o estabelecimento de um clima propício entre nós e de um certo "controle" da situação nas mãos das entrevistadas. Isso, de certa forma, permitiu, no momento da entrevista, um clima de menos tensão por parte das professoras.

No que se refere a um contexto mais amplo, mas estreitamente vinculado à situação imediata da entrevista, um ponto importante a considerar foi a minha presença nesse processo, inevitavelmente marcada como aluna, naquela época, de uma instituição de ensino superior que incomodou e desacomodou, em nível nacional, principalmente a partir dos anos 80, o chamado ensino tradicional de Língua Portuguesa: a Unicamp, que teve papel decisivo na implementação do processo de reformulação de ensino de língua materna (FARACO, 2008). Todas as entrevistadas tinham ciência desse papel e certamente me viam como uma representante das ideias defendidas por essa instituição. Por isso, algumas questôes, às vezes verbalizadas, foram-me colocadas inicialmente: o que a aluna / a instituição iria fazer com os dados recolhidos nas entrevistas?; para que, de fato, serviriam eles?; não haveria algum "aproveitamento dos dados" para que mais críticas negativas pudessem ser instaladas ou reiteradas contra o ensino tradicional de Língua Portuguesa a partir do material gravado?

\footnotetext{
${ }^{8}$ As entrevistas foram gravadas em áudio e depois transcritas. Posteriormente os textos transcritos foram revisados pelas entrevistadas com o apoio dos originais gravados.
} 
Por outro lado, se a imagem da instituição certamente as incomodava, algumas inquietações também se colocaram para mim em relação ao que seria narrado pelas professoras: o que privilegiariam contar do passado do ensino vivido?; o que seria preciso silenciar?; o que pretendiam e queriam, de fato, revelar?

Foi no imbricamento desses contextos repletos de avaliaçôes sobre o "outro" - a memória do ensino vivido, a expansão e interferência dos conhecimentos linguísticos no panorama nacional de ensino, a posição dos linguistas brasileiros frente ao ensino tradicional de língua, o papel da Unicamp, a minha posição como pesquisadora, dentre outras avaliações - que os discursos se processaram na instância concreta das entrevistas.

Foi possível verificar, de modo geral, que, ao narrarem, o assunto ensino da gramática foi bastante enfatizado por quase todas as entrevistadas. Para dar uma ideia, mesmo aproximativa, desse panorama, retomo informações que vieram à tona e que, segundo elas, correspondiam a suas práticas cotidianas.

Lembraram-se, por exemplo, de vários tipos de exercícios passados aos alunos em tarefas ou em avaliações, como preencher espaço com a pessoa verbal adequada, conjugar um tempo verbal em todas as pessoas, aplicar a crase devidamente, empregar o verbo haver impessoal, pontuar corretamente um texto apresentado sem pontuação, distinguir um aposto de um vocativo, dentre muitos outros exercícios, apresentados por livros didáticos ou elaborados por elas mesmas, sempre tendo a variedade culta como referência.

Disseram também que alguns pontos no ensino gramatical eram privilegiados, como o estudo do verbo e suas conjugações e o estudo da sintaxe, principalmente, a análise sintática.

Contaram que usavam um compêndio gramatical como instrumento linguístico de apoio; duas utilizavam o de Domingos Paschoal Cegalla, a Novissima Gramática da Lingua Portuguesa, que, segundo elas, era o preferido, naquela época; já uma outra fazia uso do compêndio de Rocha Lima.

Quanto à frequência dessas aulas, a maioria deixou transparecer que era alta, com a observação de que esse estudo era conjugado com o texto, o que, de certa forma, "amenizaria" o estudo estritamente gramatical:

[...] a gramática entrava com que frequência na sala de aula?

Ah, todos os dias: pelo texto, né? Texto de leitura, interpretação dos textos, sinônimo, vocabulário, né? E a gramática. (Profa. B).

Foi possível perceber que o ensino de gramática era uma atividade presente e defendida por três professoras por várias razões; entretanto, ao lado 
disso, foi possível identificar uma outra posição, colocada por uma professora, para quem o ensino da gramática, embora não defendido, era contemplado por força da tradição, por imposição curricular e, por isso, trabalhado com menor frequência. Para ela, a prioridade estava na leitura e escrita, não na gramática:

[...] sobre a gramática, o que que a senhora me conta?

Ah, nada. Nada [risos da entrevistada]. Eu era obrigada a ensinar gramática, concordância, aquela coisa toda, né? Eu... eu acho que eu... nós tínhamos um livro que era a gramática do Rocha Lima, se não me engano, que estava na época, estava em moda, na época. Você conhece essa gramática?

Conheço.

É, uma gramática difícil pra burro, né? Ai que horror! Então a gente trabalhava com essa gramática, em cima dessa gramática. Eu tenho a impressão que quem escolhi... tinha escolhido a gramática era a Juracy. Eu não tinha talento pra ele.[...]

Então a gramática ficava em segundo plano em relação às outras atividades?

Pra mim [com ênfase], sim. Pra mim, sim. (Profa. A).

No grupo predominante, favorável ao ensino gramatical, foi possível perceber outras três regularidades, que mais uma vez as identificava.

Uma delas se referia à ideia - deixada bem clara - de que o ensino gramatical praticado não era baseado em memorização nem em exceçôes, pensamento esse que pôde ser recuperado em várias passagens, como as a seguir:

Porque eu sempre [com ênfase] repudiei o estudo de memória, da gramática decorativa. Repudiei. Gramática, eles aprendiam através do texto [com ênfase]. (Profa. B).

[falando sobre as questôes de gramática da sabatina] Como eu disse pra você, perguntas importantes [com ênfase]. Nada de casca de banana. Nada pergunta de descobrir lá um coletivo que nunca ninguém usou na vida e que eu também precisava olhar num dicionário pra saber o que que era. Era a língua atual, erros comuns que as pessoas faziam na redação. (Profa. C).

Uma outra regularidade era a de que o trabalho gramatical nascia do texto, ou seja, o ensino da gramática não se dava isoladamente, mas na articulação com o trabalho sobre o texto. Na passagem, a seguir, uma das professoras narra como isso se concretizava na sua aula: 
[...] a minha gramática, a que mais me atraía era aquela que nascia do texto.

Como era isso?

Do estudo do texto. Sabe? Por isso, um estudo do texto era demorado, era uma coisa lenta, mas rica. Porque, conforme as palavras e as oraçōes vinham surgindo, sempre havia uma coisa, um aspecto a que era preciso chamar a atenção. E isso não era uma coisa nem preparada, pode-se dizer, porque era uma coisa que o texto acordava na gente, no momento. E disso eu gostava. Essa coisa que saía daquilo e dava uma volta, não é? a respeito ou de uma origem de palavra ou de uma metáfora. Aqui é que estava... pra mim todo o encantamento do estudo. (Profa. D).

Mais um ponto bastante destacado foi o de que o ensino da gramática é necessário, sustentado por justificativas como as seguintes:

É fundamental, porque ela é que vai dar uma base para a redação. $\mathrm{O}$ plural de um substantivo... Você diz a gramática inteira, não é ?

Isso. Inteira.

Pois é, então. Uma acentuação de palavra, tudo isso são noções que são fundamentais. Elas fazem parte da base mesmo, do substrato do aprendizado de língua. Não se pode deixar de lado a gramática... (Profa. D).

[...] através da gramática porque ela é um instrumento para utilizar bem a língua. (Profa. C).

A gramática como base para a elaboração da redação, como meio para a boa utilização da língua são argumentos que procuram deixar clara a posição de que o aluno tem benefícios com esse estudo, de que o ensino gramatical é indispensável: "Não se pode deixar de lado a gramática" (Profa . D).

$\mathrm{Se}$, por um lado, essas regularidades - um ensino não-memorativo nem baseado em exceçôes, apoiado no texto e indiscutivelmente necessário, pois benéfico - estão certamente associadas a ideias que circulavam na época em que trabalharam, por outro lado, a necessidade de trazê-las e destacá-las está associada, e muito, às condições de produção das entrevistas.

Todos esses pontos podem ser entendidos como recados que precisavam ser dados à entrevistadora e, principalmente, à instituição que ela representava, que se colocou desfavoravelmente ao ensino tradicional de Língua Portuguesa, e, em especial, a como se desenvolvia o ensino da gramática.

É em função dessas condições que se pode entender que os aspectos enfatizados não são gratuitos; ao contrário, têm um endereço certo e se colocam 
como uma defesa do ensino que realizaram, uma tentativa de reversão da imagem do ensino de gramática e de seu próprio trabalho, acometido com uma série de críticas, principalmente a partir dos anos 1970. A seleção de aspectos enfatizados vem ao encontro do que um dia lhes foi criticado e, certamente por isso, foram esses os aspectos destacados e não outros. A oportunidade de serem entrevistadas lhes dava espaço para o que, no entender delas, precisava ser falado e, principalmente, retificado. Tomam a palavra como direito de se defenderem de uma imagem que as incomodava e como direito de avaliarem uma tradição de ensino da qual fizeram parte pelo lado "de dentro", em contraposição aos que "de fora" o analisaram. Certamente aproveitaram o momento para dar uma resposta ao enunciado que, de certa forma, monologizou os sentidos do passado do ensino de gramática: era preciso dar continuidade ao movimento dos significados.

Além dessas regularidades, outras tomadas de posição foram colocadas por esse grupo de professoras $(\mathrm{B}, \mathrm{C}$ e $\mathrm{D})$ : são críticas negativas ora dirigidas à forma como alguns de seus colegas, décadas atrás, entendiam e desenvolviam o ensino da gramática, ora dirigidas aos rumos que o ensino gramatical veio a tomar nos dias de hoje.

Disseram que se contrapunham ao trabalho realizado por alguns professores, pois estes, sim, e não elas, faziam um trabalho de memorização, de que discordavam totalmente, seja no estudo da morfologia, seja na sintaxe. Assim, procuraram delimitar, mais uma vez, seu jeito de trabalhar, afastando uma imagem que lhes era imputada e que, no seu entender, não correspondia ao trabalho realizado. A passagem, a seguir, aponta nessa direção:

Eu tinha, por exemplo, colegas de Português, professores contratados na mesma escola, que não... tinham, não faziam essa espécie de trabalho; se apegavam mais à parte decorativa de regras, se preocupavam mais com a acentuação das palavras, não faziam esse trabalho de redação, redação de vez em quando os alunos faziam.[...] Os alunos se limitavam a memorizar regras, né? O verbo concorda com o sujeito [uma imitação do que se fazia no ensino] em número e pessoa, né? Sujeito simples, verbo no singular; sujeito composto leva o verbo ao plural... Mas não tinham assim aquela prática. Era um estudo assim mais de memória. $[\ldots]$ Que resulta...

Resulta, não! Não dá resultado, né? Porque eu acho que é partindo do texto que o aluno aprende, né? (Profa. B).

A outra crítica, já esperada, se colocava contra o ensino de gramática conforme defendido no processo de reformulação do ensino de Língua 
Portuguesa, pois, segundo uma das professoras, nele há espaço para o uso nãoformal da língua em sala de aula, o que não condiz, no seu entender, com o que deva ser ensinado.

O encaminhamento das entrevistas deixou claro que o assunto ensino da gramática foi o que mais incomodou a maioria das entrevistadas e as colocou em posição ora de defesa (à procura de resguardar a própria imagem), ora de ataque (por meio de críticas ao atual ensino gramatical construído em novas bases). Em função disso, inconformadas com a imagem de "gramatiqueira", manifestaram sua avaliação contrária ao que circula na esfera acadêmica: o ensino praticado não se fazia apenas nos limites da gramática nem se reduzia a ensinar gramática.

Foi possível perceber pela leitura das entrevistas que o universo escolar do qual as docentes fizeram parte, num mesmo período de tempo, era perpassado por diferentes vozes ou distintas posições axiológicas relativas ao ensino da gramática, traduzidas em diferentes formas de entender e desenvolver esse ensino.

Uma primeira se identifica com a defesa desse ensino por si mesmo, com predomínio da atividade gramatical sobre qualquer outra no ensino de língua, por meio de práticas já muito utilizadas como a memorização e o trabalho descontextualizado. Pode-se denominá-la a voz da tradição, que naquele período - dos anos 1950 aos 1970 - ainda continuava a ressoar após um longo processo histórico de atuação no ensino de língua materna (SOARES, 2002). É interessante observar que essa voz não é ocupada pelas entrevistadas, mas é relembrada (é falada) por elas como uma prática corrente de outros colegas professores, da qual, segundo elas, sempre se distanciaram.

Uma outra voz também se coloca na direção da defesa do ensino gramatical, mas, nesse caso, não como um trabalho isolado, autônomo; ao contrário, sempre articulado ao texto. Essa voz, de certa forma, "inovadora" frente às novas exigências de uma nova escola - em início de processo de democratização - em emergência a partir dos anos 1950, pode ser entendida como uma voz de transição, pois embora ainda valorize a atividade gramatical - como defende a da tradição - traz algo novo, o trabalho entre conteúdo gramatical e texto, prática essa que aos poucos passa a ser utilizada por professores e livros didáticos de língua portuguesa. Das quatro entrevistadas, três (professoras $\mathrm{B}, \mathrm{C}$ e D) se colocam alinhadas a essa voz, o que sinaliza uma tendência que se instalou no interior do quadro de ensino gramatical daquela época.

Essa tendência é confirmada por Soares (2002, p. 167): 
ora é na gramática que se vão buscar elementos para a compreensão e a interpretação do texto, ora é no texto que se vão buscar estruturas lingüísticas para a aprendizagem da gramática. Assim, nos anos 1950 e 1960, ou se estuda a gramática a partir do texto ou se estuda o texto com os instrumentos que a gramática oferece.

Esse novo rumo em progressão no ensino de português, entretanto, não significou que a gramática perdesse a sua primazia sobre o texto, fato que, segundo Soares, pode ser explicada pela força da tradição que vem dos tempos do sistema jesuítico e persistiu do século XVI até as primeiras décadas do século $\mathrm{XX}$, e talvez também pelo espaço vazio que o abandono da retórica e poética deixou no ensino.

A partir do que diz essa autora, o ensino gramatical passou de uma convivência autônoma de dois manuais, uma gramática e uma seleta de textos, para uma etapa de articulação gramática e texto.

Essa articulação, rememorada por três entrevistadas, vem delinear uma fase do ensino tradicional de língua, fruto de uma transformação crescente das condições sociais, culturais e políticas e do acesso democratizado à escola, que passou a exigir modificações das funções e objetivos da instituição escolar e, por consequência, alterações nas disciplinas escolares (id. ibid.).

Tal articulação, segundo Soares, pode ser verificada nos livros didáticos publicados nos anos 1950 e 1960 em que gramática e texto passam a formar um só livro, embora para essa autora, mesmo dentro dessas condições, a gramática e o texto ainda guardarem relativa autonomia no manual didático dos anos 1950. É o caso, por exemplo, do manual mais presente nas aulas dos anos 1950, o Português no ginásio, de Raul Moreira Lellis, em que a gramática ocupa uma metade do livro e os textos (conservando ainda o nome de "antologia"), a outra metade. Já nos anos 1960, a "fusão" / aproximação ocorre nos livros de forma mais acentuada por meio da organização de unidades: cada uma delas é constituída por texto para interpretação e por tópico gramatical. Um exemplo dessa organização é a própria coleção didática publicada pela autora nos anos 1960, Português através de textos (SOARES, 2002, p.168). ${ }^{9}$

\footnotetext{
${ }^{9}$ Embora esse trabalho articulado gramática / texto seja entendido por Soares como uma alteração frente ao que se realizava antes dos anos 1950, ou seja, o trabalho da gramática como conteúdo autônomo, esse entendimento não é compartilhado pelos linguistas em geral. Ou melhor, quando se referem ao ensino tradicional, falam da articulação gramática e texto como uma pseudo-articulação, um disfarce de novo
} 
Mais uma outra voz que se destaca é aquela que, concretizada nas palavras da professora $\mathrm{A}$, prioriza as atividades de leitura e escrita e dá à atividade de gramática um caráter bastante secundário, apenas trabalhado por força de uma exigência escolar. Para o período em questão, trata-se certamente de uma postura "destoante", embora a gramática ainda estivesse presente, pois se colocava na contramão do que as outras vozes previam. Poder-se-ia chamá-la de voz do "novo" (ou quem sabe, de "vanguarda"?), pois, para aquela época, era algo que escapava às rotinas previstas no ensino gramatical e, em última instância, no ensino de língua portuguesa.

Além dessas vozes, uma outra certamente norteou todas as entrevistas: a voz da academia, que pode ser entendida certamente como "o" receptor presumido de todo o dizer das professoras. Foi certamente na direção dela, naquele momento corporificado pela minha presença como entrevistadora que a palavra de cada professora se colocou.

Tomando por base as diferentes vozes que se sobressaem no corpus em questão, mais um aspecto pode ser analisado: as relações que essas vozes mantêm entre si, ou, utilizando a terminologia da perspectiva bakhtiniana, as relaçôes dialógicas, que podem ser caracterizadas como "relaçōes de sentido que se estabelecem entre enunciados, tendo como referência o todo da interação verbal (e não apenas o evento da interação face-a-face)" (FARACO, 2003, p. 63).

A leitura das entrevistas confirma a visão bakhtiniana de que cada voz estabelece relação, dialoga com outra(s), seja por meio de um confronto ou acolhimento, aceitação ou recusa, interseção ou hibridização (FARACO, 2003, p. 80), dentre outras formas de relaçôes, pois cada uma ganha vida no colocar-se com a outra e com as outras, num permanente movimento.

Dentre as várias relaçōes dialógicas que se estabelecem, algumas podem ser observadas. É o caso, por exemplo, da relação de reiteração que a voz da tradição (como o próprio nome diz) mantém com o passado do ensino gramatical, respondendo a ele de forma a dar-lhe continuidade, privilegiando práticas de tempos anteriores à década de 50 , como é o caso da valorização da memorização, do trabalho descontextualizado e autônomo com a gramática. Percebe-se uma relação de confirmação, de extensão de posturas de ensino

que representa mera continuação do antigo ensino voltado essencialmente para a gramática. Melhor dizendo, no discurso dos linguistas, a aproximação gramática / texto, propalada pelas professoras, e também por Soares, em nada mudava a essência do ensino de língua: sempre gramatical (ANGELO, 2005). 
outrora consagradas, e que se firma em direção ao já vivido, a um tempo anterior e, ao reiterá-lo, abre espaço para a manutenção, a confirmação de uma forma de ensinar o conteúdo gramatical.

Já a voz de transição estabelece, com a voz tradicional, uma relação dialógica de hibridização, à medida que não descarta o trabalho gramatical, reconhecendo sua importância, mas o modifica dando a ele uma forma diferenciada de ser trabalhado, associando-o ao texto. Pode-se perceber, assim, que a voz de transição, até certo ponto, mantém uma relação de divergência com a da tradição ("Resulta, não! Não dá resultado, né? Porque eu acho que é partindo do texto que o aluno aprende, né?" Profa. B), mas não para negála totalmente, antes para marcar os seus limites, ampliando-os.

Já a voz a que denominamos do "novo" estabelece uma relação não harmoniosa com as outras duas: mantém uma relação de divergência com a voz de transição, ao dar grande espaço para o trabalho com o texto, para atividades de leitura e escrita, sem guardar a idéia de explorá-lo para ensinar um determinado conteúdo gramatical (como faz a voz de transição), e uma relação de enfrentamento com a voz da tradição, ao colocar, em segundo plano, ou até mesmo desconsiderar as atividades gramaticais.

Essa mesma voz estabelece, entretanto, uma relação de interseção com um enunciado que vem a se colocar algumas décadas depois, nos anos 80 , pela voz da academia - a reformulação do ensino de língua portuguesa - que defende, dentre outros aspectos, a atenção central ao texto, prioridade às práticas de leitura e produção de texto, estudo gramatical como prática complementar ou secundária. Entretanto, embora essa relação dialógica se estabeleça, isso não significa uma relação de harmonização plena com o processo de reformulação do ensino, visto que tais vozes não compartilham, por exemplo, as mesmas concepções de linguagem e de língua, visto que são diferenciadas em distintos períodos da história dos estudos da linguagem (décadas de 50,60 e década de 80).

Mais uma relação dialógica a observar é a que se estabelece entre a voz de transição e a da academia, evidenciada nas palavras das professoras B, C e D e certamente dirigidas a mim no processo de rememoração. Trata-se de uma relação de conflito, de recusa de uma imagem divulgada pela voz da academia a respeito do trabalho desenvolvido pela voz de transição (articulação gramática / texto), entendido como essencialmente gramatical. Essa relação dialógica funda um desentendimento recíproco entre essas vozes, que, em termos gerais, pode ser assim entendido: por mais que os sujeitos da voz de transição digam que o ensino gramatical realizado por elas era articulado com a prática de leitura 
de textos, e representava, por isso, uma prática nova, não isolada (comparada com o que faziam seus professores) e um ganho em termos de resultados obtidos com os alunos, esses enunciados são "compreendidos" pelos sujeitos da voz da academia como a continuidade de antigas e improdutivas práticas de ensino gramatical. Tal relação que se estabelece é o que Maingueneau (2005) chama de relação polêmica, que leva a uma interincompreensão discursiva. Diz o autor: "para constituir e preservar sua identidade no espaço discursivo, o discurso não pode haver-se com o Outro como tal, mas somente com o simulacro que constrói dele." (p. 103).

Essa mesma relação dialógica de conflito permite também compreender a colocação de críticas negativas emitidas pelos sujeitos da voz de transição ao processo de reformulação do ensino de língua portuguesa, defendido pela academia nos anos 80 .

Embora outras relações dialógicas se estabeleçam entre as vozes aqui elencadas, restrinjo-me às apresentadas, por entender que contemplam os objetivos deste trabalho.

Pelas várias posições axiológicas depreendidas no corpus e pelas relações que mantêm entre si, é possível perceber que já não é sem problemas associarmos o painel do ensino de gramática de décadas atrás a uma realidade unívoca, transparente, materializada na expressão "ensino tradicional de gramática". Certamente esse panorama guarda muitas peculiaridades, muitas relações a serem ainda conhecidas. ${ }^{10}$

\section{Considerações finais}

A análise das entrevistas permitiu verificar que o panorama do ensino gramatical de Língua Portuguesa de décadas atrás é mais complexo que aquele que tem sido amplamente divulgado na esfera acadêmica: um quadro simplificado, homogêneo, uníssono. Nele foi possível reconhecer a voz da

\footnotetext{
${ }^{10}$ Entendo que não só o ensino de gramática mas também o ensino tradicional de língua portuguesa como um todo devam ser pesquisados. Registro uma passagem de uma das entrevistas em que a professora, ao rememorar, avalia o seu trabalho e as suas aulas: "Então a gente procurou trazer essa renovação. [...] elas eram tradicionais, mas com uma lufada [com ênfase] nova. Nós estávamos dentro de um mundo que se estava renovando. E numa época em que era perigoso até escrever. Mas já escreviam como o Brasil Urgente (jornalzinho publicado por seus alunos que eram ligados ao movimento estudantil durante o período da ditadura militar e que, segundo ela, circulava no interior da própria escola.)" (Profa. C).
} 
"tradição" ao lado de outras, como a da transição e do novo, também em circulação na esfera escolar.

Embora a existência dessas diferentes posturas avaliativas não tenha representado, em nenhum dos casos, a eliminação do ensino da gramática das aulas de Língua Portuguesa, algumas delas, como a da transição e a do novo, tiveram a função, de certa forma, de arejar, transformar progressivamente $o$ ensino gramatical ao longo do tempo.

A investigação realizada permitiu não só entender o ensino gramatical de décadas passadas como um panorama multifacetado, concretizado nas diferentes vozes, como também perceber a existência de um jogo intrincado de relações dialógicas que essas várias vozes mantêm entre si. É nesse jogo de relaçôes múltiplas, de aproximação, conflito, reiteração, que se constrói o percurso desse ensino, em que a permanência de uma tradição e a instauração de novas posturas coexistem num mesmo período de tempo.

Por fim, cumpre dizer que a escuta da palavra da professora de Língua Portuguesa, rememorando seu passado profissional, teve um papel determinante nessa pesquisa, pois permitiu que aflorassem outros sentidos sobre o ensino gramatical de décadas passadas que não os legitimados num contexto social mais amplo, o acadêmico, ou seja, serviu como instrumento propulsor para que o diálogo sobre esse ensino continuasse a produzir réplicas.

\section{Referências bibliográficas}

ANGELO, G. L. Revisitando o ensino tradicional de lingua portuguesa. Tese de doutorado. 2005. Tese (Doutorado em Linguística Aplicada ao Ensino de Língua Materna) - Instituto de Estudos da Linguagem, Universidade Estadual de Campinas, Campinas, 2005.

BAKHTIN, M. Marxismo e filosofia da linguagem. Trad. Michel Lahud e Yara Frateschi Vieira. 3. ed. São Paulo, 1929/1986.

BAKHTIN, M. O discurso no romance. In: BAKHTIN, M. Questôes de literatura e de estética: a teoria do romance. 4. ed. Trad. Aurora Fornoni Bernardini et al. São Paulo: Ed. UNESP e HUCITEC, 1934-35/1998.

BAKHTIN, M. Observações sobre a epistemologia das ciências humanas. In: BAKHTIN, M. Estética da criação verbal. Trad. Maria Ermantina Galvão. 3. ed. São Paulo: Martins Fontes, 1974/ 2000.

BAKHTIN, M. O problema do texto. In: BAKHTIN, M. Estética da criação verbal. Trad. Maria Ermantina Galvão. 3. ed. São Paulo: Martins Fontes, 1959$61 / 2000$. 
BAKHTIN, M. Os gêneros do discurso. In: BAKHTIN, M. Estética da criação verbal. Trad. Maria Ermantina Galvão. 3. ed. São Paulo: Martins Fontes, 1952$53 / 2000$.

BOSI, E. Memória e sociedade: lembranças de velhos. São Paulo: Companhia das Letras, 1994.

BOSI, E. O tempo vivo da memória: ensaios de psicologia social. São Paulo: Ateliê Editorial, 2003.

BRANDÃO, H. H. N. Introdução à análise do discurso. 2. ed. rev. Campinas: Editora da Unicamp, 2004.

CHERVEL, A. História das disciplinas escolares: reflexões sobre um campo de pesquisa. Teoria \& Educação, Porto Alegre, Pannonica, n. 2, p. 177-229, 1990.

FARACO, C. A. Linguagem \& diálogo. As idéias lingüísticas do Círculo de Bakhtin. Curitiba: Criar, 2003.

FARACO, C. A. O ensino do português no Brasil: alguns paradoxos e desafios. In: FARACO, C. A. Norma culta brasileira: desatando alguns nós. São Paulo: Parábola Editorial, 2008, p. 185-198.

GARNICA, A. V. M. (Re)traçando trajetórias, (re)coletando influências e perspectivas: uma proposta em História Oral e Educação Matemática. In: BICUDO, M. A. V., BORBA, M. de C. (Org.). Educação Matemática: pesquisa em movimento. São Paulo: Cortez, 2004, p.151-163.

GUEDES-PINTO, A. L. Rememorando trajetórias da professora-alfabetizadora: a leitura como prática constitutiva de sua identidade e formação profissionais. 2000. Tese (Doutorado em Lingüística Aplicada ao Ensino de Língua Materna) - Instituto de Estudos da Linguagem, Universidade Estadual de Campinas, Campinas, 2000.

KATO, M. O ensino de línguas após a implantação da lingüística. In: Boletim da Abralin, 4, 1983, Recife, p.51-59.

MAINGUENEAU, D. Gênese dos discursos. Trad. Sírio Possenti. Curitiba: Criar, 2005.

MEIHY, J. C. S. B. Manual de História Oral. São Paulo: Loyola, 1996.

SOARES, M. B. Português na escola. História de uma disciplina curricular. In: BAGNO, M. (Org.). Lingüistica da norma. São Paulo: Edições Loyola, 2002, p.155-177.

Recebido em 18 de setembro de 2008. Aprovado em 19 de março de 2009. 